\title{
Cytoprotective effects of cerium and selenium nanoparticles on heat-shocked human dermal fibroblasts: an in vitro evaluation
}

This article was published in the following Dove Press journal:

International Journal of Nanomedicine

7 April 2016

Number of times this article has been viewed

Bo Yuan

Thomas J Webster

Amit K Roy

Chemical Engineering Department, College of Engineering, Northeastern University, Boston, MA, USA
Correspondence: Thomas J Webster Chemical Engineering Department, College of Engineering, Northeastern University, 313 Snell Engineering Center, 360 Huntington Avenue, Boston, MA 02II5, USA

Email th.webster@neu.edu

\begin{abstract}
It is a widely accepted fact that environmental factors affect cells by modulating the components of subcellular compartments and altering metabolic enzymes. Factors (such as oxidative stress and heat-shock-induced proteins and heat shock factors, which upregulate stress-response related genes to protect affected cells) are commonly altered during changes in environmental conditions. Studies by our group and others have shown that nanoparticles (NPs) are able to efficiently attenuate oxidative stress by penetrating into specific tissues or organs. Such findings warrant further investigation on the effects of NPs on heat-shock-induced stress, specifically in cells in the presence or absence (pretreated) of NPs. Here, we examined the cytoprotective effects of two different NPs (cerium and selenium) on heat-induced cell death for a model cell using dermal fibroblasts. We report for the first time that both ceria and selenium NPs (at $500 \mu \mathrm{g} / \mathrm{mL}$ ) possess stress-relieving behavior on fibroblasts undergoing heat shock. Such results indicate the need to further develop these NPs as a novel treatment for heat shock.
\end{abstract}

Keywords: ceria, heat shock, nanotechnology, cell death, nanomedicine, protective

\section{Introduction}

Eukaryotic living cells, due to mitochondrial respiration, are constantly producing free radicals and other oxidants. These redox activities are essential to cellular functions, including homeostasis and temperature regulation. ${ }^{1}$ It has been shown that environmental factors greatly influence cellular differentiation in adult normal and stem cells. ${ }^{2}$ Cells are protected from these conditions by the induction of several stress-response related genes. Broadly, in vitro, cells can be easily stressed by several means such as physical, chemical, and biological stimuli. Currently, several studies indicate that the cellular stressing phenomena could be extended to studying drug design, toxicity, and dedifferentiation (stemness). ${ }^{1-3}$ The model could be easily utilized to study the cytoprotective role of nanoparticles (NPs). However, the relationship between stress factors (heat shock) and induction or differentiation of cells has not been elucidated in great detail to date. Generally, heat shock proteins (HSPs) play crucial roles in protecting cells against environmental stresses, such as heat shock, low serum, chemicals, and pathogenic bacteria. ${ }^{3,4}$ Among the HSP family, the $70 \mathrm{kDa}$ HSPs are the most responsible for intracellular chaperone and extracellular immunoregulatory functions.

The recent expansion of nanotechnology provides a large assortment of NPs that differ in chemical composition, size, shape, surface charge and chemistry, and coating and dispersion status. ${ }^{5}$ NPs are intriguing for numerous medical applications due to 
the large surface-to-volume ratio (allowing for easy control over surface energy) and small size to penetrate cells and target intracellular components. A study has shown that NPs possess antioxidant properties and are able to efficiently attenuate oxidative stress by penetrating specific tissues or organs, even when administered at low concentrations, and have been found to increase the lifespan of model organisms. ${ }^{6}$

Here, we investigated the protective effects of ceria and selenium NPs on heat-stressed (shocked) human dermal fibroblast (HDF) cells. Recent studies have highlighted the positive role that both ceria and selenium NPs can play to kill bacteria and cancerous cells without adversely affecting healthy cell functions. ${ }^{7}$ It is anticipated that this investigation will shed light on the role of various NPs on stress-induced skin (HDF) cells and the physiological effects of these NPs in extending cellular life span. Therefore, we believe these studies could lead to the development of a new means of introducing antioxidants into cells or designing of new antioxidants, which can result in a breakthrough in antioxidantresistant drug discovery for the modulation of aging and longevity.

Hence, the aim of this study was to examine the effect of ceria and selenium NPs in the attenuation of stress-induced cell death in HDF cells and explore their potential to be used in cosmetics and in the prevention of aging-related skin injuries.

\section{Materials and methods}

\section{Preparation of ceria and selenium NPs} Ceria NPs

The stock solutions of cerium and sodium hydroxide were prepared separately by dissolving and mixing $21.7 \mathrm{~g}$ of $\mathrm{Ce}_{3} \mathrm{NO}_{3}$ in $100 \mathrm{~mL}$ of water and by adding $2 \mathrm{~g}$ of $\mathrm{NaOH}$ to $50 \mathrm{~mL}$ of distilled water in a beaker. In another beaker, $8.5 \mathrm{~mL}$ of $\mathrm{Ce}_{3} \mathrm{NO}_{3}, 5 \mathrm{~mL}$ of sodium hydroxide, and $75 \mathrm{~mL}$ of distilled water were added. The solution was stirred for 1 hour and heated at $150^{\circ} \mathrm{C}$ for 24 hours.

\section{SeNPs}

The selenium nanoparticles (SeNPs) were prepared as previously reported. ${ }^{8,9}$ SeNPs were prepared by mixing $3 \mathrm{~mL}$ of $0.1 \mathrm{M}$ glutathione and $3 \mathrm{~mL}$ of $0.025 \mathrm{Na}_{2} \mathrm{SeO}_{3}$. Next, $2 \mathrm{M}$ of $\mathrm{NaOH}$ and distilled water were added to maintain a $\mathrm{pH}$ of approximately 11 . The mixture was then transferred to a centrifuge tube and centrifuged at 5,000 rpm for 10 minutes at $25^{\circ} \mathrm{C}$. The precipitate was washed with distilled water and dried.

\section{CeNP and SeNP characterization}

The NPs have been extensively characterized in terms of size, zeta potential, concentration, shape, and surface topography using dynamic light scattering (DLS), qNano, transmission electron microscopy (TEM), and scanning electron microscopy. ${ }^{10}$ DLS (Zetasizer, NanoZS, Malvern Instruments, Malvern, UK) experiments were performed to analyze the particle size and distribution of NPs. After the particles in the suspension were dried and formulated into a powder, the presence of ceria and selenium was confirmed by X-ray photoelectron spectroscopy (XPS) using a Phi model 04-548 dual anode X-ray source (nonmonochromated) and hemispherical analyzer (Phi model 10-360). The data were collected using the $\mathrm{Al} \mathrm{K} \alpha(1,486.6 \mathrm{eV})$ source operating at $300 \mathrm{~W}$. Careful calibration and fitting of gold at the Au4f7 photoelectron peak set the system's minimum full width at half maximum of $1.2 \mathrm{eV}$ with an $80 \%$ Gaussian/Lorentzian distribution at a pass energy of $35.75 \mathrm{eV}$. Background subtraction was performed using the integrated Shirley method. ${ }^{11}$ X-ray diffraction (XRD) (PANalytical Philips X-ray Diffractometer, X'Pert Pro, PANalytical, Almelo, the Netherlands) was also used to confirm the crystalline structure of the particles. ${ }^{12}$

\section{Cell culture}

The use of human cells in this study was approved by the Institutional Animal Care and Use Committee of Northeastern University. Neonatal human dermal foreskin fibroblasts, HDF (American Type Culture Collection, Manassas, VA, USA), were cultured in Dulbecco's Modified Eagle's Medium (DMEM, Gibco, Carlsbad, CA, USA) with high glucose and L-glutamine, supplemented with $10 \%$ heat-inactivated fetal bovine serum (FBS, from Gibco), $100 \mathrm{U} / \mathrm{mL}$ penicillin $\mathrm{G}, 100 \mathrm{mg} / \mathrm{mL}$ streptomycin (Gibco), and $250 \mu \mathrm{g} / \mathrm{mL}$ amphotericin $\mathrm{B}$ and were grown to confluency on $100 \mathrm{~mm}$ plates. The cells were maintained at $37^{\circ} \mathrm{C}$ in a humidified chamber under a $5 \% \mathrm{CO}_{2}$ and $95 \%$ air atmosphere. Fibroblasts were used at passage numbers 6-8 in every experiment, and the culture medium was changed every 2 days. The growth characteristics and appearance of cells by light microscopy were unchanged up to passage 10 . When the cultures reached $90 \%$ confluence, the cells were detached from the plates with $500 \mu \mathrm{L}$ of TripleE (Gibco). Next, the single-cell suspension was placed in $15 \mathrm{~mL}$ screw cap tubes and centrifuged. The cell pellet was reconstituted in FBS-supplemented DMEM complete medium.

For heat-shock treatment and viability assays, cells were routinely seeded in 6-well plates at a density of approximately $5,000 / \mathrm{cm}^{2}$ and were subcultured and counted every 5 days. 
Seed 5,000 cells $/ \mathrm{cm}^{2} \mathrm{HDF}$ cells in a

6 -well plate and incubate for $48 \mathrm{~h}$

Add Ce and Se nanoparticles into the wells separately

Heat the labeled plates at $42^{\circ} \mathrm{C}$ and $45^{\circ} \mathrm{C}$ for 30,60 , and 120 minutes. Remove the plates after heating and add fresh media to recover for $24 \mathrm{~h}$

Figure I Experimental paradigm.

Abbreviations: HDF, human dermal fibroblast; Ce, cerium; Se, selenium; h, hours.

Cell morphology was visualized under a microscope. The population doubling times (PDs) were calculated as follows: $P D s=\log 2$ (number of cells harvested at subculture/ number of cells initially seeded).

\section{Treatment}

For heat shock experiments, cells were pretreated with NPs $(500 \mu \mathrm{g} / \mathrm{mL})$, then the plates were placed in a $5 \% \mathrm{CO}_{2}$ incubator exposing the cells to temperatures of $37^{\circ} \mathrm{C}, 42^{\circ} \mathrm{C}$, and $45^{\circ} \mathrm{C}$ (Figure 1). The temperature was maintained for 1 hour. After the heat treatment, the plates were taken out, the medium was changed, and the cells were allowed to recover from heat stress for 24, 48, and 72 hours.

\section{Cell viability}

HDF cells were grown to confluency on $100 \mathrm{~mm}$ plates, and the viability was assayed by the well-established trypan blue dye exclusion method. The cells were checked under the microscope and photographed during the recovery period. The number of cells was counted manually and plotted.

\section{Statistical analysis}

All experiments were repeated in triplicate at least three times each. Differences between mean values were determined using analysis of variance followed by Student's $t$-tests.

\section{Results}

We first prepared and characterized cerium and selenium NPs. Following NP synthesis, TEM (JEM 1010, JEOL, Tokyo, Japan) was first used to observe particle size, distribution, and morphology at $80 \mathrm{keV}$ accelerated voltage, and the results are shown in Figures 2 and 3. Particles were analyzed on a carbon-coated copper grid as described earlier. ${ }^{13}$ Results revealed that the particle size was approximately $3 \mathrm{~nm}$ for ceria NPs and $150 \mathrm{~nm}$ for SeNPs. DLS results confirmed that there was no significant change in the size of the particles after storing them for 1 month in the refrigerator, $4^{\circ} \mathrm{C}^{7}$ XPS and XRD confirmed the expected chemistry and crystallinity. ${ }^{10,11,14}$

The first experiment was carried out by pretreating the semiconfluent culture of the HDF cells with NPs. Based on our previous studies, we had selected a $500 \mu \mathrm{g} / \mathrm{mL}$ dose of NPs. ${ }^{11,14}$ The cells were exposed to heat by placing the plates in respective incubators as indicated $\left(37^{\circ} \mathrm{C}, 42^{\circ} \mathrm{C}\right.$, and $\left.45^{\circ} \mathrm{C}\right)$. As shown in Figure 4, at the end of 24 hours of incubation, there was no change in HDF cell number (proliferation rate) or cell morphology at the indicated NP concentration $(500 \mu \mathrm{g} / \mathrm{mL})$ compared to the control group at $37^{\circ} \mathrm{C}$ (untreated). However, at 48 hours, the HDFs had a strong effect to the change in temperature $\left(45^{\circ} \mathrm{C}\right)$ in the control group. Most importantly, much less cell death was observed in the NP-treated cultures (either selenium or ceria) compared to controls (Figure 5). After 3 days, cell death increased in the control groups compared to the NP-treated ones as shown in Figure 6. It is evident that at $37^{\circ} \mathrm{C}$ there was no change in cell number among the groups. Cells pretreated with NP (at the dose of $500 \mu \mathrm{g} / \mathrm{mL}$ ) appeared to resist HDF heat shock at $42^{\circ} \mathrm{C}$ and $45^{\circ} \mathrm{C}$ (Figure 7). The viability of the HDF cells decreased approximately $30 \%-50 \%$ in all groups as heat was applied by increasing the temperature from $37^{\circ} \mathrm{C}$ to $45^{\circ} \mathrm{C}$. As 

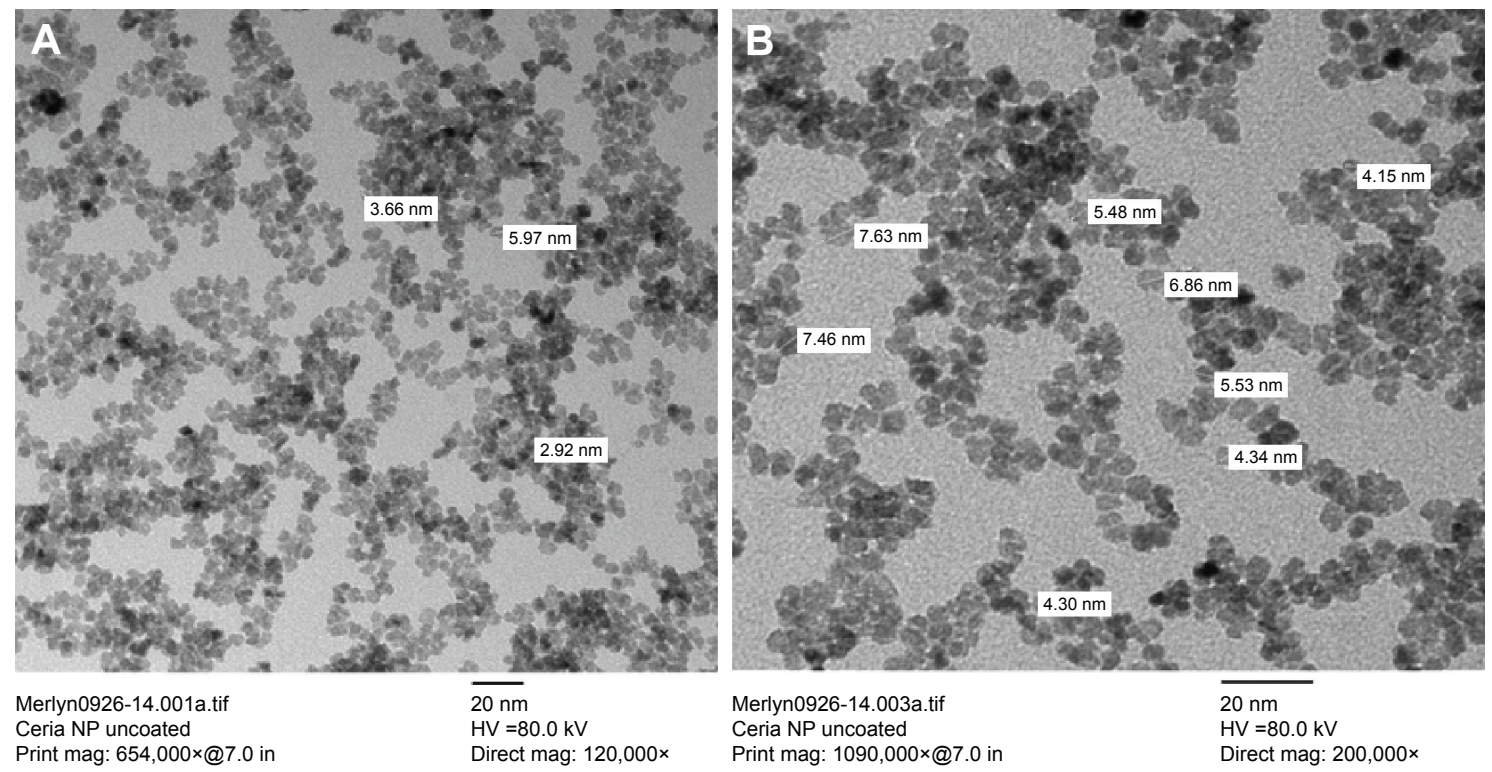

Figure 2 TEM images of ceria NPs.

Notes: Scale bars are $20 \mathrm{~nm}$. (A) 120,000× magnification; (B) 200,000× magnification. HV is the accelerated voltage used during analysis.

Abbreviations: NP, nanoparticle; TEM, transmission electron micrograph.

expected, more cell death was noticed at the 72-hour recovery for the control cells. NP-induced resistance in cell death was noticeable in all three time points (24-72 hours), but the effect was significant at the 48 -hour recovery (Figure 7). Compared to controls, there was a twofold increase in cell number in ceria-treated HDF and a $25 \%$ increase in cell number in the selenium-treated group after 72 hours at $45^{\circ} \mathrm{C}$.

\section{Discussion}

The temperature and time dependence of the heat-mediated death in HDF cells were evaluated in the presence of NPs. As shown in Figure 2, HDF cells were grown and pretreated with cerium and selenium NPs in 6-well plates. Heat was selected as a stressor, and the cells were heat shocked for 1 hour with increasing temperatures of $37^{\circ} \mathrm{C}, 42^{\circ} \mathrm{C}$, and
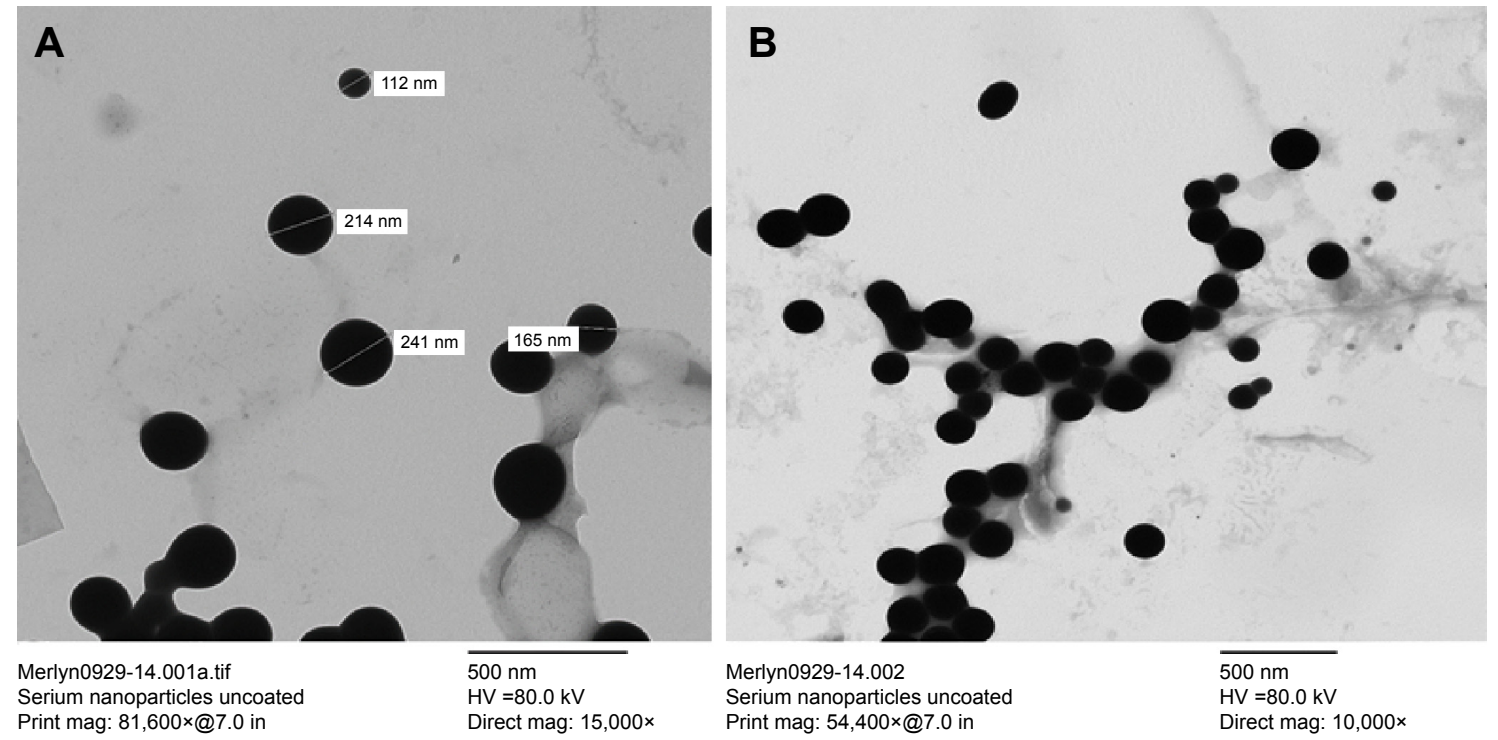

Figure 3 TEM images of selenium NPs.

Notes: Scale bars are $500 \mathrm{~nm}$. (A) 15,000× magnification; (B) 10,000× magnification. HV is the accelerated voltage used during analysis.

Abbreviations: NPs, nanoparticles; TEM, transmission electron micrograph. 
$37^{\circ} \mathrm{C} 24 \mathrm{~h}$
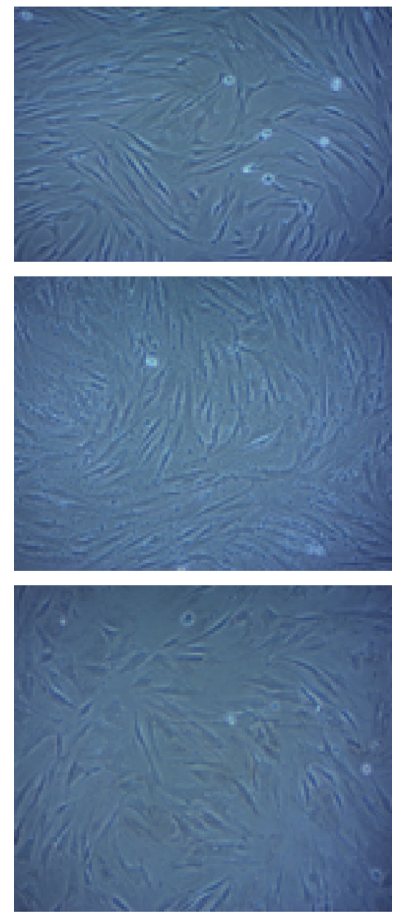

$42^{\circ} \mathrm{C} 24 \mathrm{~h}$

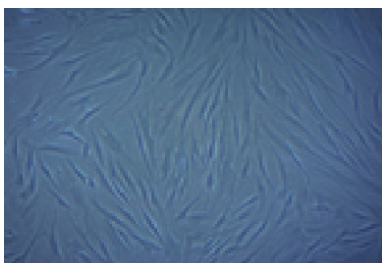

$\mathrm{Ce}$

(500 $\mu \mathrm{g} / \mathrm{mL})$

$\mathrm{Se}$

(500 $\mu \mathrm{g} / \mathrm{mL})$
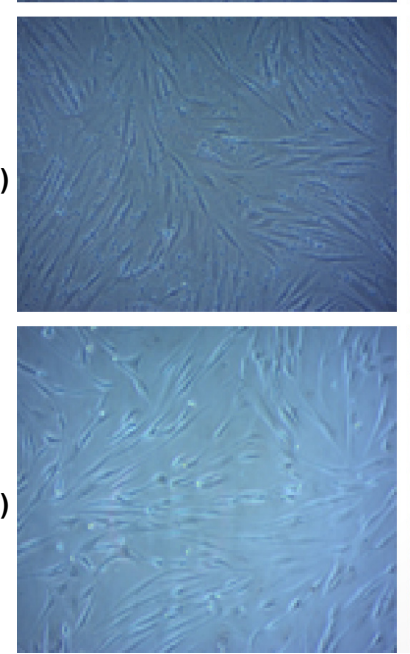

$45^{\circ} \mathrm{C} 24 \mathrm{~h}$
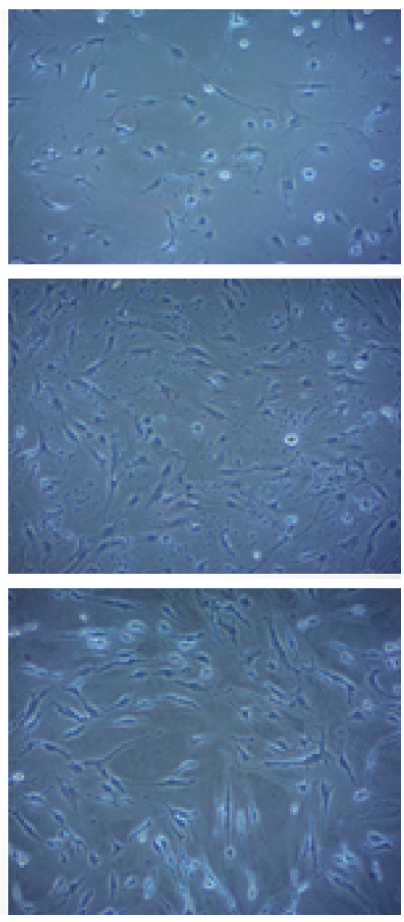

Figure $4 \mathrm{HDF}$ cells preincubated with ceria and selenium NPs ( $500 \mu \mathrm{g} / \mathrm{mL}$ for 24 hours) and heat stressed at $37^{\circ} \mathrm{C}, 42^{\circ} \mathrm{C}$, and $45^{\circ} \mathrm{C}$ for I hour. Note: Cells were recovered in fresh medium for 24 hours.

Abbreviations: HDF, human dermal fibroblasts; NPs, nanoparticles; h, hours; Ce, cerium; Se, selenium.

$37^{\circ} \mathrm{C} 48 \mathrm{~h}$
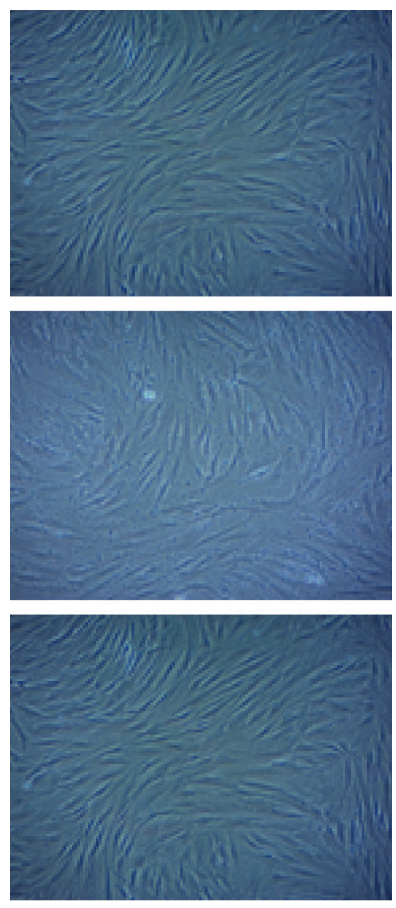

$42^{\circ} \mathrm{C} 48 \mathrm{~h}$

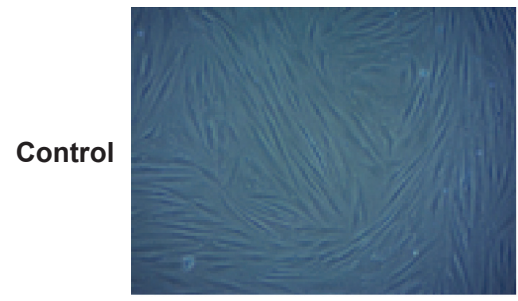

Ce

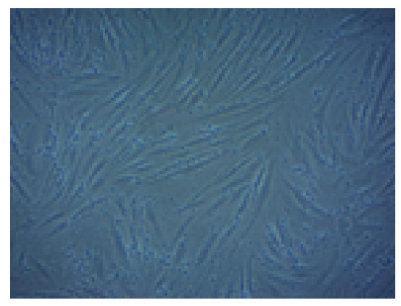

Se

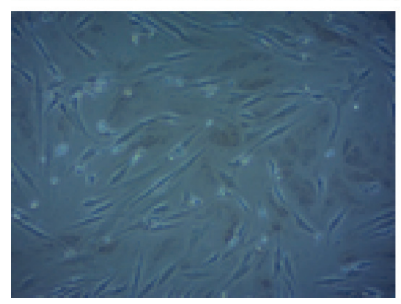

$45^{\circ} \mathrm{C} 48 \mathrm{~h}$
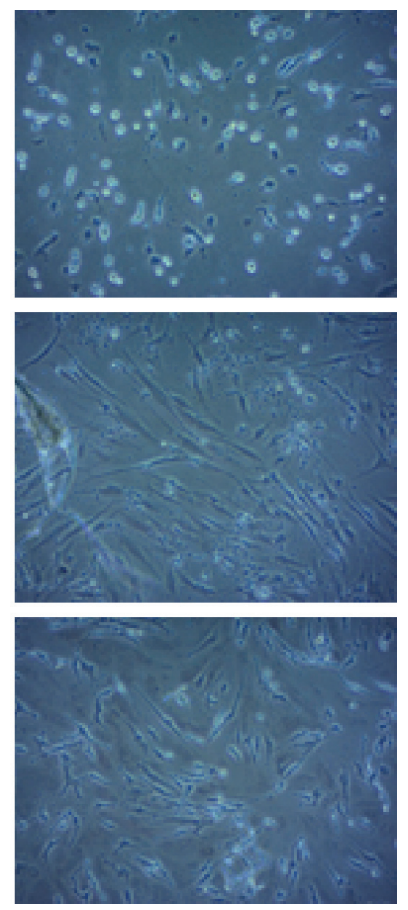

Figure 5 Following preincubation with ceria and selenium NPs $\left(500 \mu \mathrm{g} / \mathrm{mL}\right.$ for 24 hours), cells were heat stressed at $37^{\circ} \mathrm{C}, 42^{\circ} \mathrm{C}$, and $45^{\circ} \mathrm{C}$ for I hour. Note: Cells were recovered for 48 hours.

Abbreviations: NPs, nanoparticles; h, hours; Ce, cerium; Se, selenium. 
$37^{\circ} \mathrm{C} 72 \mathrm{~h}$
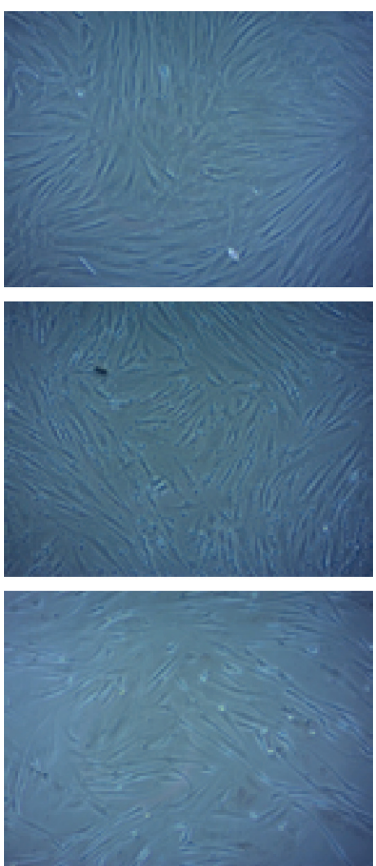

$42^{\circ} \mathrm{C} 72 \mathrm{~h}$

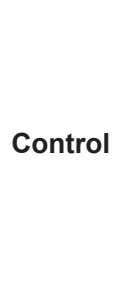

$\mathrm{Ce}$
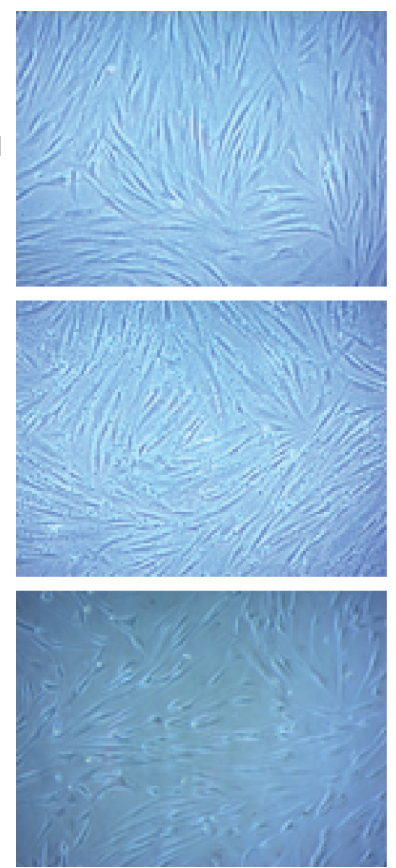

$45^{\circ} \mathrm{C} 72 \mathrm{~h}$
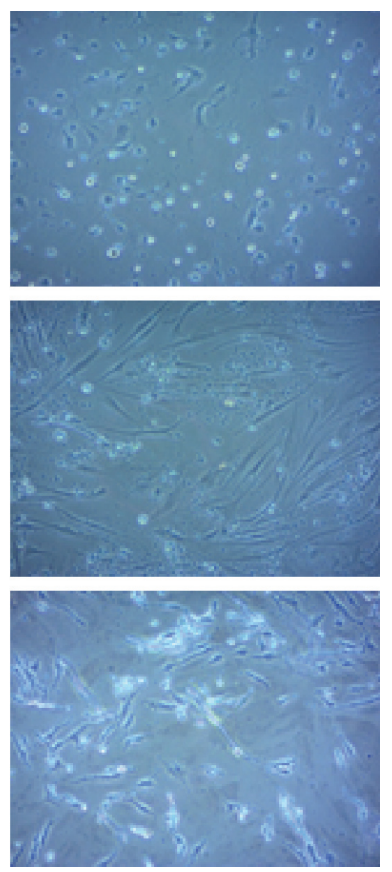

Figure 6 Following preincubation with ceria and selenium NPs $\left(500 \mu \mathrm{g} / \mathrm{mL}\right.$ for 24 hours), cells were heat stressed at $37^{\circ} \mathrm{C}, 42^{\circ} \mathrm{C}$, and $45^{\circ} \mathrm{C}$ for I hour. Note: Cells were recovered for 72 hours.

Abbreviations: NPs, nanoparticles; h, hours; Ce, cerium; Se, selenium.
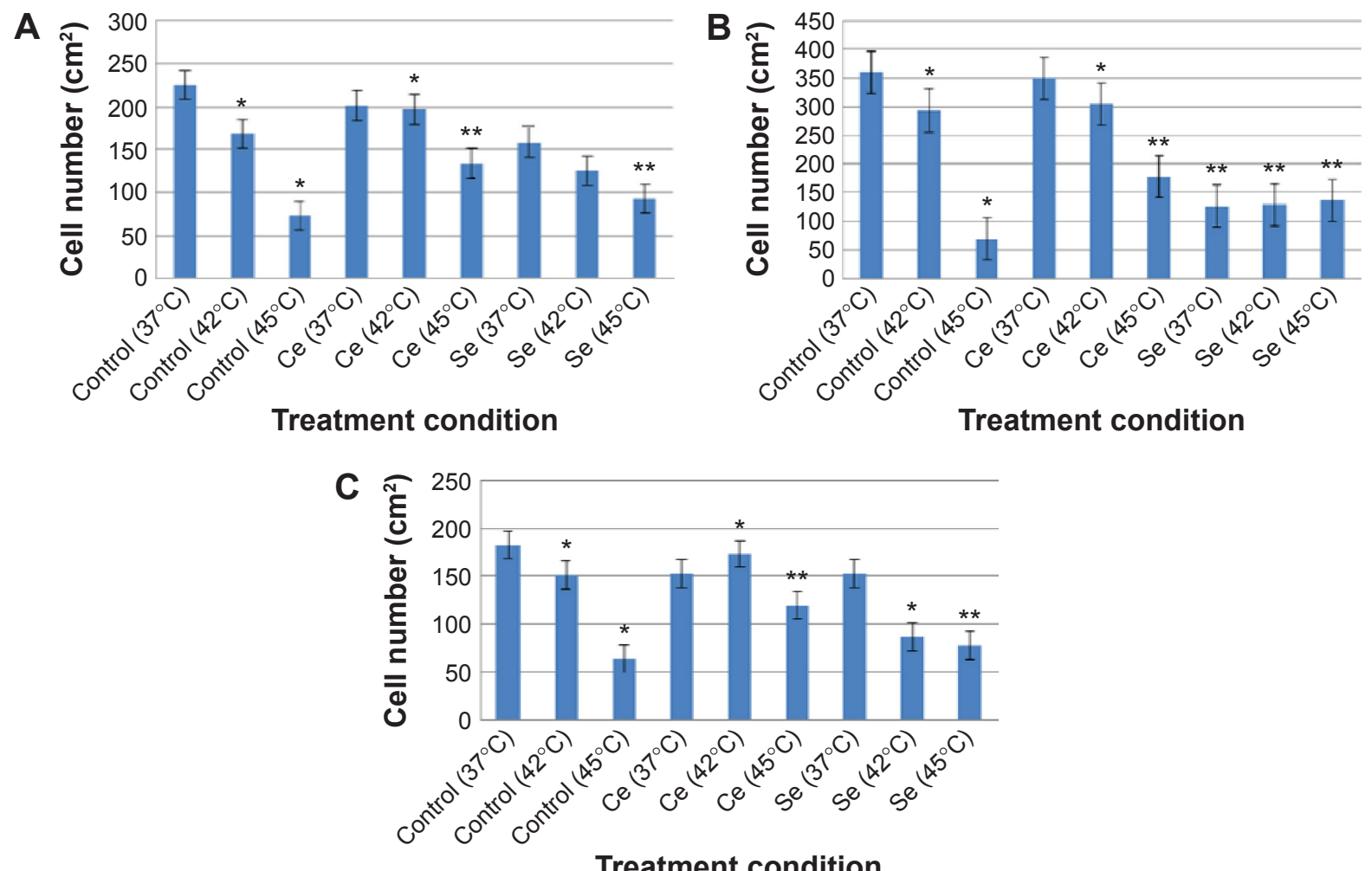

Figure 7 Effects of ceria and selenium NP on the recovery of heat-treated HDF cells at various time points.

Notes: Cell recovery with NPs at (A) 24 hours, (B) 48 hours, and $(\mathbf{C}) 72$ hours. Data $=$ mean $\pm \mathrm{SEM} ; \mathrm{N}=3$; at respective time points: $* P<0.0$ I compared to next lowest temperature, same NP treatment, and same time period; **P $<0.01$ compared to respective control at the same temperature and at the same time period. $Y$-axis should be multiplied by 10 .

Abbreviations: HDF, human dermal fibroblasts; NPs, nanoparticles; SEM, standard error of the mean; Ce, cerium; Se, selenium. 
$45^{\circ} \mathrm{C}$, followed by recovery at 24,48 , and 72 hours after replacing the media. The plates were photographed, and the number of viable cells was determined using a phase-contrast microscope at $10 \times$ magnification.

It has been shown that ceria and selenium can be used as antioxidants. ${ }^{13}$ Because of ceria's ability to switch from $\mathrm{Ce}^{3+}$ to $\mathrm{Ce}^{4+}$ reversibly at physiological $\mathrm{pH}$ values, cerium oxide NPs (nanoceria) have shown great potential as antioxidant and radioprotective agents in cancer therapy. ${ }^{6}$ Our previous studies reported that ceria could be successfully used for alleviating cellular stress by oxidants. ${ }^{13,15}$ This suggests that the NPs play some important intracellular scavenging role in cellular stress. It is also known that in the stress-induced cell response model, the heat-shocked proteins play a key role in early events. ${ }^{16,17}$ However, the role of these NPs as cell scavengers through the induction of heat-shocked proteins and their genes in cellular stress is not fully characterized. Future experiments will be focused on determining the exact mechanisms of how ceria and selenium in this study were able to decrease fibroblast death due to heat shock. The present results open the door for the extensive study of selenium and ceria across a wide range of events such as reversing disease, aging, and other ailments.

\section{Conclusion}

In this study, HDFs were killed by heating above $40^{\circ} \mathrm{C}$. Maximum cell death was noted or observed when cells were incubated at $45^{\circ} \mathrm{C}$ for 1 hour. Preincubation with the currently fabricated ceria or selenium NPs for 24 hours resisted cell death. Ceria was more effective than selenium in protecting cells against heat-induced cell death. In summary, we demonstrated for the first time that heat-stress-induced cell death could be reversed by priming the HDF cells with ceria and selenium NPs. This suggests that NP pretreatment might induce some antiapoptotic genes that are needed to protect cells from stressrelated cell injury, which will be the focus of future studies.

\section{Acknowledgment}

The authors thank Northeastern University for funding this research.

International Journal of Nanomedicine

\section{Publish your work in this journal}

The International Journal of Nanomedicine is an international, peerreviewed journal focusing on the application of nanotechnology in diagnostics, therapeutics, and drug delivery systems throughout the biomedical field. This journal is indexed on PubMed Central,

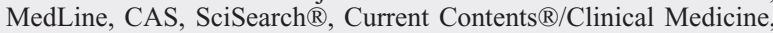

\section{Disclosure}

The authors report no conflicts of interest in this work.

\section{References}

1. Kregel KC. Heat shock proteins: modifying factors in physiological stress responses and acquired thermotolerance. J Appl Physiol. 1985;92(5): $2177-2186$.

2. Li GC, Mivechi NF, Weitzel G. Heat shock proteins, thermotolerance, and their relevance to clinical hyperthermia. Int J Hyperthermia. 1995;11(4):459-488.

3. Beere HM, Green DR. Stress management - heat shock protein-70 and the regulation of apoptosis. Trends Cell Biol. 2001;11(1):6-10.

4. Nguyen CT, Park SS, Rhee DK. Stress responses in Streptococcus species and their effects on the host. $J$ Microbiol. 2015;53(11): 741-749.

5. Li Y, He X, Yin JJ, et al. Acquired superoxide-scavenging ability of ceria nanoparticles. Angew Chem Int Ed. 2015;54:1832-1835.

6. Wason MS, Zhao J. Cerium oxide nanoparticles: potential applications for cancer and other diseases. Am J Transl Res. 2013;5:126-131.

7. Holinka J, Pilz M, Kubista B, Presterl E, Windhager R. Effects of selenium coating of orthopaedic implant surfaces on bacterial adherence and osteoblastic cell growth. Bone Joint J. 2013;95(5):678-682.

8. Karakoti AS, Monteiro-Riviere NA, Aggarwal R, et al. Nanoceria as antioxidant: synthesis and biomedical applications. JOM. 2008;60: 33-37.

9. Tran PA, Sarin L, Hurt RH, Webster TJ. Titanium surfaces with adherent selenium nanoclusters as a novel anticancer orthopedic material. J Biomed Mater Res A. 2010;93(4):1417-1428.

10. Tran PA, Webster TJ. Selenium nanoparticles inhibit Staphylococcus aureus growth. Int J Nanomedicine. 2011;6:1553.

11. Alpaslan E, Yazici H, Vargas M, Roy AK, Webster TJ. Dextran coated cerium oxide nanoparticles act as antioxidants. Paper presented at: MRS Spring Meeting, April 8, 2014, San Francisco, CA.

12. Repoux M. Comparison of background removal methods for XPS Surface Interface Anal. 1992;18:567-570.

13. Webster TJ, Ejiofor JU. Increased osteoblast adhesion on nanophase metals. Biomaterials. 2004;25:4731-4739.

14. Alpaslan E, Yazici H, Golshan NH, Ziemer KS, Webster TJ. Inhibiting bone cancer cell growth with cerium oxide. Paper presented at: Materials Research Society Spring Meeting; April 8, 2014; San Francisco, CA.

15. Zhang F, Wang P, Koberstein J, Khalid S, Chan S-W. Cerium oxidation state in ceria-nanoparticles studied with X-ray photoelectron spectroscopy and absorption near edge spectroscopy. Surface Sci. 2004; 563:74-82.

16. Ting SR, Whitelock JM, Tomic R, et al. Cellular uptake and activity of heparin functionalised cerium oxide nanoparticles in monocytes. Biomaterials. 2013;34(17):4377-4386.

17. Adler V, Schaffer A, Kim J, Dolan L, Ronai Z. UV irradiation and heat shock mediate JNK activation via alternate pathways. J Biol Chem. 1995;270:26071-26077. 